\title{
PERSEPSI DAN MOTIVASI WISATAWAN STAYCATION BERKUNJUNG KE DESA BATUR KINTAMANI DI MASA PANDEMI COVID-19
}

\author{
I Kadek Adi Palguna $^{1}$, NMS. Wijaya ${ }^{2}$, NGAS. Dewi ${ }^{3}$ \\ Email: ikadekadipalguna14101998@gmail.com¹,sofia_ipw@unud.ac.id ${ }^{2}$,susrami_ipw@unud.ac.id ${ }^{3}$ \\ ${ }^{1,2,3}$ Program Studi S1 Industri Perjalanan Wisata, Fakultas Pariwisata, Universitas Udayana
}

\begin{abstract}
Abstarct: Staycation become more of trend during the pandemic COVID, because it does not require a lot of time, money and near home. The purpose of this study was to determine the characteristics, perceptions and motivations of staycation tourist visiting the Batur Kintamani Village during the pandemic COVID-19. The sample in this study were staycation tourist in the Batur Kintamani Village during the pandemic COVID-19. The sampling technique used purposive sampling on 100 respondents. The data collection technique by: observation, interview, questionnaire and literature study. The data analysis technique used in this research is qualitatif descriptive analysis. The results of the study indicate that the characteristics of tourists are dominated by tourists aged between 21 to 30 years old, gender are dominated by female, profession are dominated by students or university students. The perception of staycation tourists getting an average attitude of agree which dominated by factor of the Batur Kintamani Village as a favorite place to take pictures. In staycation tourist motivation, push factor dominated by factor of wanting to relax or refresh during the pandemic COVID-19 and pull factor dominated by factor the beautiful view of mountain and lake are interesting to take pictures. Push factor get a higher average score than pull factor, so that the push factor becomes the dominant factor affecting staycation tourist motivation come to the Batur Kintamani Village during the pandemic COVID-19.
\end{abstract}

\begin{abstract}
Abstrak: Staycation menjadi aktivitas wisata yang menjadi trend di masa pandemi COVID-19, karena tidak memerlukan banyak waktu, biaya serta dilakukan di dekat rumah. Tujuan dari penelitian ini adalah untuk mengetahui karakteristik, persepsi serta motivasi wisatawan staycation yang berkunjung ke Desa Batur Kintamani di masa pandemi COVID-19. Sampel dalam penelitian ini adalah wisatawan staycation di Desa Batur Kintamani pada masa pandemi COVID-19. Teknik penentuan sampel menggunakan purposive sampling dengan 100 orang responden. Teknik pengumpulan data dilakukan dengan: observasi, wawancara, kuisioner dan studi pustaka. Teknik analisis data yang digunakan adalah analsis deskriptif kualitatif. Hasil penelitian menjelaskan bahwa karakteristik umur wisatawan staycation didominasi oleh wisatawan yang berumur antara 21 sampai 30 tahun, jenis kelamin didominasi perempuan jenis pekerjaan didominasi pelajar atau mahasiswa. Persepsi wisatawan staycation didominasi oleh persepsi Desa Batur Kintamani sebagai tempat favorit untuk berfoto. Dalam motivasi wisatawan staycation, faktor pendorong mendapatkan sikap setuju yang didominasi faktor keinginan untuk bersantai atau menyegarkan kembali pikiran di masa pademi COVID-19 dan faktor penarik didominasi faktor panorama gunung dan danau yang indah dan menarik untuk berfoto. Faktor pendorong mendapatkan skor rata-rata yang lebih tinggi dibandingkan faktor penarik, sehingga faktor pendorong menjadi faktor dominan mempengaruhi motivasi wisatawan staycation ke Desa Batur Kintamani di masa pandemi COVID-19.
\end{abstract}

Keywords: perception, motivation, staycation tourists, kintamani, covid-19. 


\section{PENDAHULUAN}

Sejak tanggal 2 Maret 2020, Indonesia mengalami pandemi COVID-19, Corona Virus Disease-19 (COVID-19) adalah virus yang dapat menginfeksi sistem pernapasan dan bisa menyebabkan gangguan ringan pada sistem pernapasan, infeksi paru-paru yang berat, sampai kematian. Pemerintah sempat memberlakukan lockdown serta PSBB (Pembatasan sosial berskala Besar) hingga menghimbau masyarakat untuk menerapkan kebiasaan baru yang disebut dengan New Normal untuk mencegah penularan COVID-19.

Pariwisata yang menjadi sumber penghasilan utama masyarakat di Bali selama ini perkembangannya hanya terpusat di Bali Selatan, sedangkan di Bali Utara banyak terdapat daya tarik wisata yang menarik untuk dikunjungi wisatawan seperti Desa Batur Kintamani. Dalam perkembanganya daya tarik wisata Desa Batur Kintamani belum dikelola dengan maksimal, dimana angka kemiskinan tertinggi di Kabupaten Bangli terdapat di Kecamatan Kintamani.

Desa Batur Kintamani adalah daya tarik wisata yang memanfaatkan keunikan alam berupa suasana dan panorama Gunung dan Danau Batur sebagai daya tarik utama. Dari sekian banyak daya tarik wisata di Kabupaten Bangli, Desa Batur Kintamani menjadi wilayah yang paling ramai dikunjungi wisatawan dibandingkan daya tarik wisata lainnya. Hal ini dapat dibuktikan dengan data jumlah kunjungan wisatawan Kabupaten Bangli mencapai mencapai 941,410 wisatawan pada tahun 2019.

Bendasarkan informasi dari artikel (Kompas.com) pada Senin 15 Juni 2020, di tengah pandemi COVID-19 kunjungan wisatawan di Desa Batur Kintamani dikabarkan sempat mengalami peningkatan yang tinggi. Berikut adalah data kunjungan wisatawan di Desa Batur Kintamani dari bulan Januari hingga bulan Maret 2020.

Jumlah kunjungan wisatawan di Desa Batur Kintamani mengalami penurunan dari
70,004 pada bulan Januari menjadi 26,071 pada bulan Maret 2020. Walaupun mengaalami penurunan jumlah kunjungan wisatawan, namun Desa Batur Kintamani masih tetap mendominasi jika dibandingkan dengan jumlah kunjungan wisatawan di daya tarik wisata lain yang ada di Kabupaten Bangli (Dinas Pariwisata Kabupaten Bangli, 2021).

Beberapa daya tarik wisata di Desa Batur Kintamani yang selalu menjadi pilihan dalam penawaran paket-paket wisata bagi wisatawan mancanegara maupun wisatawan nusantara seperti Desa Trunyan, Penelokan, Toya Bungkah, Museum Geopark dan objek wisata lainnya (Suarka \& Kusumadewi, 2020).

Dengan suasana dan kondisi alam serta panorama yang menarik menjadikan berbagai kegiatan yang dapat dilakukan wisatawan di Desa Batur Kintamani seperti berfoto, minum kopi sambil bersantai restoran maupun kafe, touring motor, mendaki gunung sambil menikmati matahari terbit (sunrice), wisata tirta (berendam air panas), dan jogging, serta bersepeda (cycling).

Pada masa pandemi COVID-19 wisatawan lebih memperhatikan self-distancing serta penerapan standar protokol COVID-19 yang menyebabkan banyak wisatawan memilih tinggal di rumah selama liburan mengunjungi daya tarik wisata di dekat tempat tinggal yang disebut dengan staycation. Staycation tidak memerlukan biaya yang banyak sehingga wisata jenis ini menjadi trend di masa pandemi dan saat ini banyak wisatawan yang memilih melakukan staycation di Desa Batur Kintamani.

Dalam proses kunjungan wisatawan, berbagai faktor dapat mempengaruhi keputusan wisatawan tersebut untuk berkunjung atau tidak. Faktor tersebut meliputi karakteristik, persepsi serta motivasi wisatawan. Karakteristik wisatawan dapat dibagi menjadi trip descriptor dan tourist descriptor. Karakteristik berdasarkan trip descriptor dibedakan menjadi lebih spesifik berdasarkan 
tujuan dari perjalanan. Sedangkan Tourist descriptor merupakan karakteristik wisatawan berdasarkan karakter sosio demografis, sosio psikografis, dan geografis.

Adanya pandemi COVID-19 memiliki dampak yang besar terhadap persepsi dan motivasi wisatawan. Dalam Suprihatin, W. (2020) dijelaskan bahwa jika di masa sebelum pandemi COVID-19 kebutuhan wisatawan didasari atas kebutuhan fisiologis (rekreasi), maka ketika pandemi ini kebutuhan akan keamanan dan keberlangsungan hidup fisik menjadi prioritas. Meningkatnya kekhawatiran terinfeksi virus COVID-19 ketika melakukkan kegiatan wisata saat ini sangat berpengaruh pada keputusan wisatawan untuk melakukan kegiatan wisata atau tidak.

\section{Pada masa pandemi COVID-19} wisatawan memiliki persepsi yang berbeda dibandingkan dengan sebelum pandemi, saat pandemi wisatawan merasa khawatir terinfekfi virus COVID-19, sehingga wisatawan akan lebih memperhatikan keamanan dan kelengkapan penerapan protokol kesehatan COVID-19 dan kebersihan, serta kelestarian lingkungan. Motivasi perjalanan wisatawan selama pandemi sebagian besar terkait kebosanan dan kejenuhan karena lama diam di rumah (Pratiwi dkk, 2020). Selain itu, keunikan dari daya tarik wisata serta kebijakan pemerintah di masa pandemi COVID-19 ini juga mempengaruhi motivasi wisatawan untuk berwisata.

Penelitian karakteristik wisatawan staycation bertujuan untuk mengungkap dan mengetahui bagaimana kebutuhan dan pola perjalanan mereka, dan mengetahui persepsi serta motivasi wisatawan staycation menjadi hal yang penting karena motivasi mempengaruhi seseorang untuk melakukan kegiatan wisata sedangkan persepsi atau citra yang baik terhadap suatu daya tarik wisata akan mempengaruhi wisatawan tersebut untuk memilih dan menikmati daya tarik wisata yang dipersepsikan, sehingga dari fenomena di atas, maka penelitian ini penting dilakukan dengan tujuan:

1. Untuk mengetahui karakteristik wisatawan staycation yang berkunjung ke Desa Batur Kintamani di masa pandemi COVID-19.

2. Untuk mengetahui persepsi wisatawan staycation berkunjung ke Desa Batur Kintamani di masa pandemi COVID-19.

3. Untuk mengetahui motivasi wisatawan staycation berkunjung ke Desa Batur Kintamani di masa pandemi COVID-19.

\section{METODE}

Penelitian ini dilakukan di Desa Batur, Kecamatan Kintamani, tepatnya di tiga lokasi yakni Penelokan, Jalur Pendakian Gunung Batur dan Toya Bungkah. Adapun pemilihan lokasi penelitian ini didasari atas jumlah kunjungan wisatawan staycation teringgi di Kabupaten Bangli dari tahun 2015 hingga Bulan Maret 2020 terdapat di Desa Batur Kintamani.

Adapun variabel-variabel yang digunakan dalam penelitian ini berdasarkan teori Seaton dan Bannet (1996) sebagai variabel karakteristik wisatawan yang meliputi: Tourist Descriptor dan Trip Descriptor. Pada sub variabel persepsi wisatawan menggunakan teori dari James J. Spillanee (1987) yang meliputi facilities, attractions, infrastructure, dan transportation serta hospitality. Pada sub variabel motivasi wisatawan menggunakan teori yang dikemukakan oleh Crompton (1979) yang meliputi faktor pendorong (push factor) dan faktor penarik (pull factor).

Pengumpulan data dalam penelitian ini dilakukan dengan observasi atau pengamatan langsung oleh peneliti, wawancara dengan informan pangkal sekaligus informan kunci yakni Bapak I Made Sasmika, SST slaku Kepala Desa Batur, Kecamatan Kintamani, Kabupaten Bangli. Penyebaran kuisioner dilakukan dengan teknik purposive sampling dengan pertimbangan sampel adalah wisatawan staycation yang berkunjung ke Desa Batur Kintamani di masa pandemi COVID-19 dengan 
jumlah sampel sebanyak 100 orang, serta studi pustaka dilakukan dengan mencari data melalui buku, referensi-referensi, jurnal dan artikel di internet.

Dalam penelitian ini menggunakan analisis data deskriptif kualitatif. Analisis data deskriptif kualitatif menghasilkan data berupa kata-kata atau deskripsi, dan proses analisis deskriptif kulaitatif akan dipadukan dengan penggunaan skala likert.

\section{HASIL DAN PEMBAHASAN}

Desa Batur adalah salah satu daya tarik wisata alam dan budaya yang ada di Kecamatan Kintamani Kabupaten Bangli. Waktu tempuh menuju Desa Batur Kintamani dari Bandar Udara Internasional Ngurah Rai sekitar 120 menit dengan menempuh jarak $75 \mathrm{~km}$ sedangkan waktu yang tempuh dari Ubud sekitar 50 menit dengan jarak $30 \mathrm{~km}$. Daya tarik wisata ini berada di ketinggian \pm 1200 meter diatas permukaan laut yang menjadikan daya tarik wisata ini memiliki suhu yang sejuk. Daya tarik wisata ini berada di daerah pengunungan dan memiliki suasana yang sejuk, sehingga banyak masyarakat yang bekerja memanfaatkan lahan mereka untuk dijadikan perkebunan seperti kebun jeruk, kopi serta bawang merah yang menggunakan sistem tumpang sari. Didukung dengan lokasi yang berada di dekat danau, banyak masyarakat Desa Batur yang memilih bekerja sebagai nelayan maupun peternak. Adanya perkembangan pariwisata yang begitu pesat di wilayah Desa Batur, menjadikan banyak masyarakat mulai beralih pekerjaan menjadi pegawai dan pengusaha di bidang pariwisata seperti restoran, kafe, villa, homestay dan yang lainya. Di Desa Batur Kintamani terdapat beberapa daya tarik wisata yang sudah dikenal oleh banyak wisatawan seperti Desa Pingan, Desa Trunyan, Penelokan, Museum Geopark Batur dan Jalur Pendakian Gunung Batur, serta Area Pemandian Air Panas Toya Bungkah dan Toya Devasya. Daya tarik utaman dari Desa Batur
Kintamani adalah suasana dan Keunikan pemandangan Gunung Batur dan Danau Batur. Suasana Dan Keunikan Gunung Batur dan Danau Batur dapat dinikmati dengan jelas dari Penelokan, sehingga Penelokan menjadi tempat yang paling ramai dikunjungi wisatawan untuk menikmati suasana dan keunikan pemandangan Gunung Batur dan Danau Batur. Selain Penelokan, Jalur Pendakian Gunung Batur juga menjadi tempat yang ramai dikunjungi wisatawan untuk berwisata sambil berfoto. Jalur Pendakian Gunung Batur berlokasi di bawah Gunung Batur dan diapit oleh Danau Batur di sebelah timur, sehingga tempat ini memiliki keunikan alam tersendiri. Di Toya Bungkah juga terdapat beberapa daya tarik wisata yang menawarkan air panas sebagai daya tarik wisata utamanya. Dari awal tahun 2020 Desa Batur kintamani mengalami penurunan jumlah kunjungan wisatawan yang sangat drastis dikarenakan adanya pandemi COVID-19 yang meresahkan dan mewajibkan semua khalangan untuk menerapkan protokol kesehatan seperti diam di rumah, rajin mencuci tangan dan menggunakan hand sanitezer, menggunakan masker serta menjaga jarak dengan orang lain. Akibat adanya pandemi COVID-19 yang begitu meresahkan menyebabkan banyak wisatawan ragu untuk berwisata, sehingga pemerintah menghimbau semua khalangan khusunya pelaku pariwisata di bali untuk menyediakan fasilitas pendukung protokol kesehatan COVID-19 seperti sabun dan tempat cuci tangan serta pembatasan jumlah wisatawan agar tidak terjadi kerumunan. Pengusaha maupun masyarakat di Desa Batur Kintamani telah menerapkan protokol kesehatan pandemi COVID-19 dengan baik yang dapat dilihat di setiap kafe, restoran, homestay, villa, hotel, maupun di daya tarik wisata telah menyediakan sabun dan tempat cuci tangan untuk wisatawan. Tindakan tersebut merupakan salah satu upaya dari pemerintah dan pengusaha pariwisata menjamin keamanan wisatawan dan menurunkan kekhawatiran wisatawan terinfeksi virus pandemi COVID-19. Namun 
masih terdapat beberapa wisatawan yang tidak menggunakan masker ketika berwisata, sehingga pemerintah sering melakukan tindakan razia masker di sepanjang jalan di Desa Batur Kintamani.

Berdasarkan hasil penelitian karakteristik wisatawan staycation yang berkunjung ke Desa Batur Kintamani di Masa Pandemi COVID-19 yang disebarkan kepada 100 orang wisatawan, diketahui bahwa karakteristik berdasarkan umur didominasi oleh wisatawan staycation yang berumur antara 21 tahun sampai 30 tahun dengan dengan persetase sebesar 75\%, karakteristik jenis kelamin didominasi oleh wisatawan staycation yang bejenis kelamin perempuan dengan persentase sebesar 59\%, karakteristik pekerjaan didominasi oleh wisatawan staycation yang bekerja sebagai pelajar atau mahasiswa dengan persentase sebesar $57 \%, \quad$ karakteristik pendidikan terakhir didominasi oleh wisatawan staycation yang memiliki pendidikan terakhir SMA/SMK/Sederajat dengan persentase sebesar $40 \%$, karakteristik status pernikahan didominasi oleh wisatawan staycation yang belum menikah dengan persentase sebesar $87 \%$ , karakteristik berdasarkan Kabupaten/Kota asal wisatawan didominasi oleh wisatawan staycation yang berasal dari Kota Denpasar dengan persentase sebesar 25\%, karakteristik hobi didominasi oleh wisatawan staycation yang memiliki hobi olahraga dengan persentase sebear 33\%, karakteristik berdasarkan akomodasi yang digunakan didominasi oleh wisatawan staycation yang menggunakan akomodasi villa dengan persentase sebesar $56 \%$, karakteristik lama kunjungan didominasi oleh wisatawan staycation yang berkunjung antara 2 hari sampai 3 hari dengan persentase sebesar 51\%, karakteristik besarnya pengeluaran biaya didominasi oleh wisatawan staycation yang mengeluarkan biaya kunjungan antara Rp. 110.000 sampai Rp. 300.000 dengan persentas sebesar $38 \%$, karakteristik teman kunjungan didominasi oleh wisatawan staycation yang berkunjung bersama teman dengan persentase sebesar $68 \%$, karakteristik berdasarkan transportasi yang digunakan didominasi oleh wisatawan staycation yang menggunakan kendaraan motor pribadi dengan persentase sebesar 52\%, karakteristik daya tarik utama kunjungan didominasi oleh wisatawan staycation yang mengunjungi daya tarik wisata Gunung Batur dan Danau Batur dengan persentase sebesar 55\%, karakteristik pengorganisasian perjalanan didominasi oleh wisatawan staycation yang berkunjung tanpa menggunakan paket tour dengan persentase sebesar $88 \%$.

Persepsi wisatawan staycation terhadap Desa Batur Kintamani sebagai daya tarik wisata di masa pandemi COVID-19 dapat dilihat pada Tabel 1.

Tabel 1. Persepsi Wisatawan Staycation Terhadap Fasilitas

\begin{tabular}{|c|c|c|c|}
\hline No & Pernyataan & $\begin{array}{l}\text { Total } \\
\text { Skor }\end{array}$ & $\begin{array}{l}\text { Rata- } \\
\text { Rata }\end{array}$ \\
\hline 1 & $\begin{array}{l}\text { Adanya akomodasi yang } \\
\text { menerapkan standar protokol } \\
\text { kesehatan dan keamanan dari } \\
\text { pandemi COVID-19 }\end{array}$ & 423 & 4,23 \\
\hline 2 & $\begin{array}{l}\text { Adanya spot untuk berfoto, } \\
\text { jalur untuk traking/mendaki } \\
\text { gunung serta untuk } \\
\text { berolahraga (bersepeda dan } \\
\text { jogging) yang memadai dan } \\
\text { telah menerapkan standar } \\
\text { protokol kesehatan pandemi } \\
\text { COVID-19 }\end{array}$ & 418 & 4,18 \\
\hline 3 & $\begin{array}{l}\text { Adanya poster, banner, } \\
\text { stiker, dan fasilitas lainya } \\
\text { yang menghimbau } \\
\text { pengunjung dan masyarakat } \\
\text { untuk menerapkan protokol } \\
\text { kesehatan COVID-19 }\end{array}$ & 415 & 4,15 \\
\hline 4 & $\begin{array}{l}\text { Tersedianya tempat untuk } \\
\text { mecuci tangan, bak sampah } \\
\text { serta toilet yang memadai }\end{array}$ & 421 & 4,21 \\
\hline & Jumlah & \multicolumn{2}{|c|}{1677} \\
\hline & Rata-rata & \multicolumn{2}{|c|}{4,19} \\
\hline
\end{tabular}

Sumber: Hasil Penelitian, 2021. 
Berdasarkan Tabel 1, dapat dilihat bahwa secara keseluruhan sub variabel fasilitas mendapatkan sikap setuju dari wisatawan dengan skor rata-rata 4,19. Pernyataan yang memiliki perolehan nilai tertinggi adalah pernyataan adanya akomodasi yang menerapkan standar protokol kesehatan dan keamanan dari pandemi COVID-19 dengan skor total 4,23 yang mendapatkan sikap sangat setuju. Pernyataan dengan skor terendah adalah pernyataan adanya poster, banner, stiker, dan fasilitas lainya yang menghimbau pengunjung dan masyarakat untuk menerapkan protokol kesehatan COVID-19 dengan skor total 4,15 yang mendapatkan sikap setuju. Pernyataan tersedianya tempat untuk mecuci tangan, bak sampah serta toilet yang memadai mendapatkan skor total 4,21 dengan sikap sangat setuju. Terakhir adalah pernyataan adanya spot untuk berfoto, jalur untuk trakking/mendaki gunung serta untuk berolahraga (bersepeda dan jogging) yang memadai dan telah menerapkan standar protokol kesehatan pandemi COVID19 mendapatkan skor 418 dengan sikap setuju.

Tabel 2. Persepsi Wisatawan Staycation Terhadap Atraksi

\begin{tabular}{clcc}
\hline No & \multicolumn{1}{c}{ Pernyataan } & $\begin{array}{l}\text { Total } \\
\text { Skor }\end{array}$ & $\begin{array}{c}\text { Rata- } \\
\text { Rata }\end{array}$ \\
\hline 1 & $\begin{array}{l}\text { Desa Batur Kintamani } \\
\text { memiliki daya tarik alam } \\
\text { yang aman dikunjungi }\end{array}$ & 424 & 4,24 \\
\hline 2 & $\begin{array}{l}\text { Desa Batur Kintamani } \\
\text { sebagai tempat favorit } \\
\text { untuk berfoto }\end{array}$ & 436 \\
\hline & $\begin{array}{l}\text { Kegiatan minum kopi dan } \\
\text { bersantai menarik dan } \\
\text { aman dilakukan di Desa }\end{array}$ & 420 & 4,20 \\
Batur Kintamani & $\begin{array}{l}\text { Desa Batur Kintamani } \\
\text { aman dan menarik untuk } \\
\text { wisata berpertualangan } \\
\text { seperti trekking dan } \\
\text { mendaki gunung }\end{array}$ & 414 \\
\hline 5 & $\begin{array}{l}\text { Desa Batur Kintamani } \\
\text { mendukung dan aman }\end{array}$ & \\
\hline
\end{tabular}

\begin{tabular}{clcc}
\hline No & Pernyataan & $\begin{array}{c}\text { Total } \\
\text { Skor }\end{array}$ & $\begin{array}{c}\text { Rata- } \\
\text { Rata }\end{array}$ \\
\hline \multicolumn{3}{l}{$\begin{array}{l}\text { untuk melakukan aktivitas } \\
\text { joging dan bersepeda }\end{array}$} \\
\hline $\begin{array}{l}\text { Pemandian air panas di } \\
\text { Desa Batur Kintamani } \\
\text { menarik dan aman } \\
\text { dikunjungi }\end{array}$ & 376 & 3,76 \\
\hline Jumlah & 2465 \\
\hline Rata-rata & 4,10 \\
\hline
\end{tabular}

Sumber: Hasil Penelitian, 2021.

Berdasarkan Tabel 2, dapat dilihat bahwa secara keseluruhan sub variabel atraksi wisata mendapatkan sikap setuju dari wisatawan staycation dengan skor rata-rata 4,10. Pernyataan yang memiliki nilai tertinggi adalah pernyataan Desa Batur Kintamani sebagai tempat favorit untuk berfoto dengan total skor 4,36 yang mendapatkan sikap sangat setuju. Pernyataan dengan skor terendah adalah pernyataan pemandian air panas di Desa Batur Kintamani menarik dan aman dikunjungi pada masa pandemi COVID-19 dengan skor total 3,76 yang mendapatkan sikap setuju. Pernyataan daya tarik wisata alam di Desa Batur Kintamani aman dikunjungi mendapatkan skor 4,24 dengan sikap sangat setuju. Pernyataan kegiatan minum kopi dan bersantai menjadi aktivitas yang menarik dan aman dilakukan di Desa Batur Kintamani mendapatkan skor 4,21 dengan sikap sangat setuju. Pernyataan Desa Batur Kintamani adalah daya tarik wisata yang aman dan menarik untuk wisata berpertualangan seperti trekking dan mendaki gunung mendapatkan skor 4,14 dengan sikap setuju. Pernyataan Desa Batur Kintamani mendukung dan aman untuk melakukan aktivitas joging dan bersepeda mendapatkan skor 3,95 dengan sikap setuju. 
Tabel 3. Persepsi Wisatawan Staycation Terhadap Infrastruktur

\begin{tabular}{|c|c|c|c|}
\hline No & Pernyataan & $\begin{array}{l}\text { Total } \\
\text { Skor }\end{array}$ & $\begin{array}{l}\text { Rata- } \\
\text { Rata }\end{array}$ \\
\hline 1 & $\begin{array}{l}\text { Aksesibilitas menuju Desa } \\
\text { Batur Kintamani }\end{array}$ & 397 & 3,97 \\
\hline 2 & $\begin{array}{l}\text { Ketersediaan lahan parkir } \\
\text { yang memadai di Desa } \\
\text { Batur Kintamani. }\end{array}$ & 387 & 3,87 \\
\hline 3 & $\begin{array}{l}\text { Ketersediaan fasilitas } \\
\text { kebersihan seperti bak } \\
\text { sampah }\end{array}$ & 404 & 4,04 \\
\hline 4 & $\begin{array}{l}\text { Ketersediaan air bersih } \\
\text { yang memadai }\end{array}$ & 394 & 3,94 \\
\hline 5 & $\begin{array}{l}\text { Ketersediaan jaringan } \\
\text { telekomunikasi internet }\end{array}$ & 370 & 3,70 \\
\hline 6 & $\begin{array}{ll}\text { Ketersediaan } & \text { stasiun } \\
\text { pengisian bahan } & \text { bakar } \\
\text { umum (SPBU) } & \\
\end{array}$ & 389 & 3,89 \\
\hline 7 & Standar keamanan & 397 & 3,97 \\
\hline & Jumlah & \multicolumn{2}{|c|}{2738} \\
\hline & Rata-rata & \multicolumn{2}{|c|}{3,91} \\
\hline
\end{tabular}

Sumber: Hasil Penelitian, 2021.

Berdasarkan Tabel 3, dapat dilihat bahwa secara keseluruhan sub variabel infrastruktur mendapatkan sikap setuju dari wisatawan staycation dengan skor rata-rata 3,91. Pernyataan dengan skor tertinggi adalah pernyataan di Desa Batur Kintamani sudah tersedia fasilitas kebersihan seperti bak sampah dengan skor 4,04 yang mendapatkan sikap setuju. Pernyataan dengan skor terendah adalah pernyataan ketersediaan jaringan telekomunikasi internet dengan skor total 3,70 yang mendapatkan sikap setuju. Pernyataan aksesibilitas menuju Desa Batur Kintamani dan pernyataan standar keamanan mendapatkan skor yang sama, yakni dengan total skor 3,97 dengan sikap setuju. Pernyataan ketersediaan air bersih yang memadai mendapatkan skor 3,94 dengan sikap setuju. Dan pernyataan telah tersedia stasiun pengisian bahan bakar umum (SPBU) mendapatkan skor 3,89 dengan sikap setuju. Indikator yang terakhir adalah ketersediaan lahan parkir mendapatkan skor
387 dengan sikap setuju dari wisatawan staycation.

Tabel 4. Persepsi Wisatawan Staycation Terhadap Traksportasi

\begin{tabular}{clcc}
\hline No & Pernyataan & $\begin{array}{c}\text { Total } \\
\text { Skor }\end{array}$ & $\begin{array}{c}\text { Rata- } \\
\text { Rata }\end{array}$ \\
\hline 1 & $\begin{array}{l}\text { Ketersediaan kendaraan } \\
\text { umum (bus) yang bersih } \\
\text { dan aman }\end{array}$ & 337 & 3,37 \\
\hline 2 & $\begin{array}{l}\text { Kemudahan akses untuk } \\
\text { kendaraan pribadi }\end{array}$ & 408 & 4,08 \\
\hline Jumlah & \multicolumn{2}{c}{745} \\
\hline Rata-rata & \multicolumn{2}{c}{3,72} \\
\hline
\end{tabular}

Sumber: Hasil Penelitian, 2021

Berdasarkan Tabel 4, dapat dilihat bahwa secara keseluruhan sub variabel transportasi mendapatkan sikap setuju dari wisatawan staycation dengan skor rata-rata 3,72. Pernyataan yang mendapat skor tertinggi adalah pernyataan kemudahan akses untuk kendaraan pribadi menuju daya tarik wisata di Desa Batur Kintamani yang mendapatkan skor 4,08 dengan sikap setuju. Pernyataan ketersediaan kendaraan umum (bus) yang bersih dan aman mendapatkan skor 3,37 dengan katagori sikap cukup.

Tabel 5. Persepsi Wisatawan Staycation Terhadap Hospitality

$\begin{array}{llll} & & \text { Total } & \text { Rata- } \\ \text { No } & \text { Pernyataan } & \text { Skor } & \text { Rata }\end{array}$

\begin{tabular}{|c|c|c|c|}
\hline 1 & $\begin{array}{l}\text { Masyarakat lokal di Desa } \\
\text { Batur Kintamani dalam } \\
\text { memberikan pelayanan kepada } \\
\text { wisatawan telah menerapkan } \\
\text { standar protokol COVID-19. }\end{array}$ & 390 & 3,90 \\
\hline 2 & $\begin{array}{l}\text { Karyawan di daya tarik wisata } \\
\text { Desa Batur Kintamani telah } \\
\text { menerapkan standar protokol } \\
\text { COVID-19. }\end{array}$ & 407 & 4,07 \\
\hline & Jumlah & \multicolumn{2}{|c|}{797} \\
\hline & Rata-rata & \multicolumn{2}{|c|}{3,98} \\
\hline
\end{tabular}

Sumber: Hasil Penelitian, 2021. 
Berdasarkan Tabel 5, dapat dilihat bahwa secara keseluruhan sub variabel hospitality mendapatkan sikap setuju dari wisatawan staycation dengan skor rata-rata 3,98. Pernyataan yang mendapatkan skor tertinggi adalah pernyataan karyawan di daya tarik wisata Desa Batur Kintamani telah menerapkan standar protokol COVID-19 dengan skor 4,07 yang mendapatkan sikap setuju. Pernyataan kedisiplinan masyarakat lokal menerapkan standar protokol COVID-19 ketika melayani wisatawan mendapatkan skor 3,90 dengan sikap setuju.

Motivasi wisatawan staycation berkunjung ke Desa Batur Kintamani di masa pandemi COVID-19 berdasarkan faktor pendorong (Push Factor) dan faktor penarik (Pull Factor) dapat dilihat pada tabel berikut:

Tabel 6. Faktor Pendorong (Push Factor) Wisatawan Staycation

\begin{tabular}{|c|c|c|c|}
\hline No & Pernyataan & $\begin{array}{l}\text { Total } \\
\text { Skor }\end{array}$ & $\begin{array}{l}\text { Rata- } \\
\text { Rata }\end{array}$ \\
\hline 1 & $\begin{array}{l}\text { Ingin melepaskan diri sejenak } \\
\text { dari kejenuhan kegiatan sehari- } \\
\text { hari di masa pademi COVID- } 19 .\end{array}$ & 425 & 4,25 \\
\hline 2 & $\begin{array}{l}\text { Ingin mendapatkan kedamaian } \\
\text { dan ketenangan di masa pademi } \\
\text { COVID- } 19 \text {. }\end{array}$ & 421 & 4,21 \\
\hline 3 & $\begin{array}{l}\text { Ingin bersantai atau } \\
\text { menyegarkan kembali pikiran di } \\
\text { masa pademi COVID-19. }\end{array}$ & 429 & 4,29 \\
\hline 4 & $\begin{array}{l}\text { Ingin meningkatkan kesehatan } \\
\text { dengan melakukan aktivitas } \\
\text { wisata seperti mendaki gunung, } \\
\text { olahraga (bersepeda/jogging) } \\
\text { dan berendam di air panas. }\end{array}$ & 392 & 3,92 \\
\hline 5 & Ingin bermain dan bergembira & 405 & 4,05 \\
\hline 6 & $\begin{array}{l}\text { Ingin menikmati rau } \\
\text { menghabiskan waktu dengan } \\
\text { teman/keluarga. }\end{array}$ & 416 & 4,16 \\
\hline 7 & $\begin{array}{l}\text { Ingin mengunjungi daya tarik } \\
\text { wisata yang belum pernah } \\
\text { dikunjungi sebelumnya }\end{array}$ & 411 & 4,11 \\
\hline 8 & $\begin{array}{l}\text { Ingin mendapatkan pengalaman } \\
\text { atau hal baru }\end{array}$ & 408 & 4,08 \\
\hline
\end{tabular}

\begin{tabular}{|c|c|c|c|}
\hline No & Pernyataan & $\begin{array}{l}\text { Total } \\
\text { Skor }\end{array}$ & $\begin{array}{l}\text { Rata- } \\
\text { Rata }\end{array}$ \\
\hline 9 & $\begin{array}{l}\text { Ingin merealisasikan keinginan } \\
\text { yang lama terpendam untuk } \\
\text { berwisata. }\end{array}$ & 401 & 4,01 \\
\hline 10 & $\begin{array}{l}\text { Ingin meningkatkan gengsi } \\
\text { (prestise) }\end{array}$ & 362 & 3,62 \\
\hline & Jumlah & \multicolumn{2}{|c|}{4070} \\
\hline & Rata-rata & \multicolumn{2}{|c|}{4,07} \\
\hline
\end{tabular}

Sumber: Hasil Penelitian, 2021.

Berdasarkan Tabel 6, dapat dilihat bahwa secara keseluruhan faktor pendorong (push factor) mendapatkan sikap setuju dari wisatawan staycation dengan skor rata-rata 4,07. Pernyataan yang memiliki nilai tertinggi adalah pernyataan ingin bersantai atau menyegarkan kembali pikiran di masa pademi COVID-19 mendapatkan skor 4,29 dengan sikap sangat setuju. Pernyataan dengan skor terendah adalah pernyataan ingin meningkatkan gengsi (prestise) yang mendapatkan skor 3,62 dengan sikap setuju. Pernyataan ingin melepaskan diri sejenak dari kejenuhan kegiatan sehari-hari di masa pademi COVID-19 mendapatkan skor 4,25 dengan sikap sangat setuju. Pernyataan ingin mendapatkan kedamaian dan ketenangan di masa pademi COVID-19 mendapatkan skor 4,21 dengan sikap sangat setuju. Pernyataan ingin menikmati atau menghabiskan waktu dengan teman/keluarga mendapatkan skor 4,16 dengan sikap setuju. Pernyataan ingin mengunjungi daya tarik wisata yang belum pernah dikunjungi sebelumnya mendapatkan skor 4,11 dengan sikap setuju. Pernyataan ingin mendapatkan pengalaman atau hal yang baru mendapatkan skor 4,08 dengan sikap setuju. Pernyataan ingin bermain dan bergembira mendapatkan skor 4,05 dengan sikap setuju. Pernyataan ingin merealisasikan keinginan lama yang terpendam untuk berwisata mendapatkan skor 4,01 dengan sikap setuju dari wisatawan staycation. Terakhir adalah pernyataan ingin meningkatkan kesehatan dengan melakukan atraksi wisata di Desa Batur 
Kintamani mendapatkan skor 3,92 dengan sikap setuju.

Tabel 7. Faktor Penarik (Pull Factor) Wisatawan Staycation

\begin{tabular}{|c|c|c|c|}
\hline No & Pernyataan & $\begin{array}{l}\text { Total } \\
\text { Skor }\end{array}$ & $\begin{array}{l}\text { Rata- } \\
\text { Rata }\end{array}$ \\
\hline 1 & $\begin{array}{lll}\text { Kualitas } & \text { kebersihan } & \text { dan } \\
\text { keamanan } & & \end{array}$ & 391 & 3,91 \\
\hline 2 & $\begin{array}{l}\text { Adanya suasana tenang dan } \\
\text { alami yang menarik untuk } \\
\text { dinikmati sambil bersantai }\end{array}$ & 423 & 4,23 \\
\hline 3 & $\begin{array}{l}\text { Adanya panorama Gunung dan } \\
\text { Danau yang indah yang menarik } \\
\text { untuk berfoto }\end{array}$ & 439 & 4,39 \\
\hline 4 & $\begin{array}{l}\text { Tertarik untuk menikmati } \\
\text { atraksi wisata yang memacu } \\
\text { adrenalin } \\
\text { mendaki/trekking mountain }\end{array}$ & 389 & 3,89 \\
\hline 5 & $\begin{array}{l}\text { Tertarik menikmati atraksi } \\
\text { wisata untuk meningkatkan } \\
\text { kesehatan seperti jogging dan } \\
\text { berendam di air panas }\end{array}$ & 393 & 3,93 \\
\hline 6 & $\begin{array}{l}\text { Desa Batur Kintamani } \\
\text { merupakan daya tarik wisata } \\
\text { yang sedang menjadi trend saat } \\
\text { ini. }\end{array}$ & 416 & 4,16 \\
\hline 7 & $\begin{array}{l}\text { Adanya hal baru yang menarik } \\
\text { untuk diperoleh di Desa Batur } \\
\text { Kintamani di masa pademi } \\
\text { COVID-19. }\end{array}$ & 400 & 4,00 \\
\hline 8 & $\begin{array}{l}\text { Lokasi Desa Batur Kintamani } \\
\text { strategis dan mudah untuk } \\
\text { dijangkau }\end{array}$ & 397 & 3,97 \\
\hline 9 & $\begin{array}{l}\text { Biaya kunjungan ke Desa Batur } \\
\text { Kintamani pademi COVID-19 }\end{array}$ & 382 & 3,82 \\
\hline & Jumlah & & 630 \\
\hline & Rata-rata & & 03 \\
\hline
\end{tabular}

Sumber: Hasil Penelitian, 2021.

Berdasarkan Tabel 7, dapat dilihat bahwa secara keseluruhan faktor penarik (pull factor) mendapatkan sikap setuju dari wisatawan staycation dengan skor rata-rata 4,03. Pernyataan yang mendapatkan nilai tertinggi adalah pernyataan adanya panorama Gunung dan Danau yang indah yang menarik untuk berfoto dengan skor 4,39 yang mendapatkan sikap sangat setuju. Pernyataan yang mendapat skor paling rendah adalah pernyataan biaya kunjungan ke Desa Batur Kintamani murah di masa pademi COVID-19 yang mendapatkan skor 3,82 dengan sikap setuju. Pernyataan adanya suasana tenang dan alami yang menarik untuk dinikmati sambil bersantai mendapatkan skor 4,23 sikap sangat setuju. Pernyataan Desa Batur Kintamani merupakan daya tarik wisata yang sedang menjadi trend saat ini mendapatkan skor 4,16 dengan sikap setuju. Pernyataan adanya hal baru yang menarik untuk diperoleh di Desa Batur Kintamani di masa pademi COVID-19 mendapatkan skor 4,00 dengan sikap setuju. Pernyataan lokasi Desa Batur Kintamani strategis dan mudah untuk dijangkau mendapatkan skor 3,97 dengan sikap setuju. Pernyataan wisatawan tertarik menikmati atraksi wisata yang dapat meningkatkan kesehatan seperti jogging dan berendam di air panas mendapatkan skor 3,93 dengan sikap setuju. Pernyataan kualitas kebersihan dan keamanan mendapatkan skor 3,91 dengan sikap setuju. Terakhir adalah pernyataan wisatawan tertarik untuk menikmati atraksi wisata yang memacu adrenalin seperti mendaki/trekking mountain mendapatkan skor 3,89 dengan sikap setuju.

Secara keseluruhan persepsi wisatawan staycation terhadap Desa Batur Kintamani sebagai daya tarik wisata di masa pandemi COVID-19 mendapatkan sikap setuju dengan skor rata-rata 4,01. Hasil ini berarti bahwa pengelolaa daya tarik wisata di Desa Batur Kintamani di masa pandemi COVID-19 sudah dijalankan dengan baik. Pemerintah dan para pelaku usaha pariwisata serta masyarakat sudah dengan baik menjaga dan menyediakan fasilitas, atraksi, infrastruktur serta transportasi yang menarik dan memudahkan wisatawan ketika melakukan staycation. Pemerintah dan para pelaku usaha pariwisata serta masyarakat sudah dengan serius menerapkan protokol kesehatan dan memberikan pelayanan yang mampu meningkatkan rasa aman dan kenyamanan dari wisatawan staycation. 
Dalam hasil penelitian, persepsi tertinggi wisatawan staycation terletak pada persepsi Desa Batur Kintamani sebagai tempat favorit untuk berfoto. Saat ini kegiatan berfoto merupakan atraksi wisata yang paling digemari wisatawan staycation. Ini sejalan dengan Desa Batur Kintamani yang memiliki pemandangan alam yang indah dan ditambah dengan promosi yang baik, sehingga banyak wisatawan berkunjung dan melakukan staycation dengan tujuan untuk melakukan aktivitas berfoto.

Sedangkan persepsi terendah dari wisatawan staycation adalah persepsi tehadap ketersediaan kendaraan umum (bus) yang bersih dan aman. Hasil ini berarti bahwa ketersediaan kendaraan umum (bus) masih belum maksimal dalam melayani wisatawan. Sehingga pemerintah dan pelaku usaha diharapkan dapat meningkatkan ketersediaan kendaraan umum (bus) yang bersih dan aman yang dapat menjakngkau daya tarik wisata di Desa Batur Kintamani untuk mempermudah kunjungan wisatawan.

Berdasarkan hasil penelitian motivasi wisatawan staycation yang terdiri dari faktor pendorong (Push Factor) dan faktor penarik (Pull Factor), dinyatakan bahwa faktor pendorong (Push Factor) mendapatkan skor rata-rata 4,07 dengan sikap setuju dengan motivasi tertinggi adalah ingin untuk bersantai atau menyegarkan kembali pikiran. Sedangkan keinginan untuk meningkatkan gengsi (prestige) menjadi faktor pendorong (Pull Factor) terendah kunjungan wisatawan staycation.

Faktor penarik (Pull Factor) mendapatkan skor rata-rata 4,03 yang juga mendapatkan sikap setuju dengan faktor penarik tertinggi adalah adanya panorama Gunung dan Danau yang indah dan menarik untuk berfoto. Biaya atau harga produk wisata menjadi faktor pendorong (Push Factor) terendah kunjungan wisatawan staycation ke Desa Batur Kintamani di masa pandemi COVID-19.
Faktor pendorong (Push Factor) mendapatkan skor rata-rata yang lebih tinggi dibandingkan dengan faktor penarik (Pull Factor), sehingga faktor pendorong (Push Factor) lebih dominan mempengaruhi kunjungan wisatawan staycation ke Desa Batur Kintamani di masa pandemi COVID-19. Faktor pendorong (Push Factor) merupakan faktor yang berada dalam diri wisatawan, sehingga dapat dinyatakan bahwa motivasi kunjungan wisatawan staycation ke Desa Batur Kintamani di masa pandemi COVID-19 dominan dipengaruhi oleh kondisi pribadi wisatawan. Sejalan dengan yang dijelaskan oleh Fandeli (1995) dalam Suwena (2017) yang menyatakan bahwa dalam menimbulkan motivasi sangat tergantung pada diri pribadi wisatawan yang menyangkut umur pengalaman, pendidikan, emosi, kondisi fisik dan psikis.

\section{SIMPULAN DAN SARAN}

\section{Simpulan}

Berdasarkan hasil dan pembahasan, maka dalam penelitian ini dapat ditarik simpulan bahwa:

1. Karakteristik wisatawan staycation yang berkunjung ke Desa Batur Kintamani di masa pandemi COVID-19 didominasi oleh wisatawan staycation yang berumur antara 21 tahun samapai 30 tahun atau wisatawan milenial dan bejenis kelamin perempuan, bekerja sebagai pelajar atau mahasiswa, memiliki pendidikan terakhir SMA/SMK/Sederajat, belum menikah, mayoritas berasal dari Kota Denpasar, memiliki hobi olahraga, ketika berwisata cenderung menggunakan akomodasi villa dengan kunjungan selama 2 sampai 3 hari, dengan pengeluaran biaya antara $\mathrm{Rp}$. 110.000 sampai Rp. 300.000, berkunjung bersama teman dengan menggunakan kendaraan motor pribadi, tertarik pada daya tarik wisata Gunung Batur dan Danau Batur serta berkunjung tanpa menggunakan paket tour. 
2. Wisatawan staycation yang berkunjung ke Desa Batur Kintamani secara umum memiliki persepsi yang baik dengan persepsi dominan bahwa Desa Batur Kintamani sebagai tempat favorit untuk berfoto dan persepsi terendah terletak pada ketersediaan transportasi umum seperti bus yang dapat memudahkan wisatawan staycation untuk berkunjung.

3. Motivasi kunjungan wisatawan staycation ke Desa Batur Kintamani di masa pandemi COVID-19 dominan bersumber dari faktor dalam diri wisatawan dengan motivasi kunjungan tertinggi adalah untuk bersantai atau menyegarkan kembali pikiran di masa pademi COVID-19 dan motivasi pendorong terendah kunjungan wisatawan staycation adalah terletak pada keinginan untuk meningkatkan gengsi (prestise). Faktor dari luar diri wisatawan staycation yang memiliki pengaruh tertinggi adalah adanya panorama gunung dan danau yang menarik untuk berfoto di Desa Batur Kintamani, dan faktor dari luar diri wisatawan staycation yang memiliki pengaruh terendah adalah harga produk wisata di Desa Batur Kintamani.

\section{Saran}

Saran yang dapat peneliti sumbangkan dalam penelitian ini adalah:

1. Kepada pemerintah, pengusaha dan masyarakat di Desa Batur Kintamani diharapkan untuk:

a. Menjaga dan meningkatkan kualitas sarana tempat berfoto, karena berfoto menjadi atraksi wisata yang paling disukai wisatawan staycation di Desa Batur Kintamani.

b. Menambah ketersediaan kendaraan umum dan jaringan komunikasi internet yang bertujuan untuk memudahkan wisatawan staycation ketika berkunjung.

c. Mempertahankan dan menjaga keindahan Gunung dan Danau Batur, karena keindahan Gunung dan Danau Batur adalah faktor yang paling mempengaruhi motivasi kunjungan wisatawan staycation.

d. Memberikan penurunan harga produk wisata dan melakukan promosi yang lebih maksimal agar Desa Batur Kintamani lebih terkenal dan menarik lebih banyak wisatawan staycation.

e. Menyediakan tempat cuci tangan di setiap rumah, toko maupun tempattempat atrategis lain yang bertujuan untuk memudahkan wisatawan maupun masyrakat untuk mencuci tangan dan lebih memperhatikan penggunaan masker sebagai penerapan standar protokol kesehatan pandemi COVID19.

2. Kapada peneliti selanjutnya di Desa Batur Kintamani, diharapkan dapat melakukan pelitian tentang promosi dan pengelolaan kafe yang banyak dikunjungi di masa pandemi COVID-19 dengan tujuan hasil penelitian dapat bermanfaat bagi pengusaha, masyarakat, maupun pemerintah di Desa Batur Kintamani. 


\section{Kepustakaan}

Suprihatin, W. (2020). Analisis Perilaku Konsumen Wisatawan Era Pandemi Covid-19 (Studi Kasus Pariwisata di Nusa Tenggara Barat). BESTARI, 1(1), 56-66.

Dewi, L. G. L. K. Pola Perjalanan Dan Pengeluaran Wisatawan Milenial Ke Bali. Jurnal IPTA (Industri Perjalanan Wisata), 8(1), 24-29.

Priasni, T. O., Absharina, D., Rizal, M. R. R., \& Arnesia, P. D. (2020). Inovasi Staycation Dalam Bidang Digital Tourism Dengan Memanfaatkan Teknologi Internet of Things dan Virtual Reality. Prosiding SeNTIK, 4(1), 49-56.

Slamet, I. W. A., Sudiarta, I. N., \& Suardana, I. W. (2015). Persepsin Wisatawan Terhadap Aksesibilitas Dari Penelokan Menuju Objek Wisata Toya Bungkah Kecamatan Kintamani Kabupaten Bangli. Jurnal IPTA ISSN, 2338, 8633.

Bascha, U. F., Reindrawati, D. Y., Witaningrum, A. M., \& Sumardiko, D. S. (2020). Dampak Pandemi COVID-19 Terhadap Minat Masyarakat dalam Berwisata dan Sosialisasi Penerapan Protokol New Normal Saat Berwisata. Jurnal Abdidas, 1(6), 560570.

Wijaya, I. N., \& Kanca, I. N. (2017). Dampak Pengembangan Pariwisata Dalam Pengembangan Pariwisata Provinsi Bali. Soshum: Jurnal Sosial dan Humaniora, 3(2), 164.

Anggela, M. M., Karini, N. M. O., \& Wijaya, N. M. S. (2017). Persepsi dan motivasi wisatawan yang berkunjung ke daya tarik wisata Jembong di kabupaten Buleleng. Jurnal IPTA p-ISSN, 5(2), 2017.

Swabawa, A. P., \& Susanto, B. (2017). Pengembangan Pariwisata Kawasan Kintamani. Soshum: Jurnal Sosial dan Humaniora, 5(2), 114.

Witarsana, I. K., Dewi, L. G. L. K., \& Dewi, N. G. A. S. (2017). Motivasi dan Persepsi Wisatawan Mancanegara Berwisata Alam Treking Mountain Di taman Wisata Alam Gunung Batur Bukit Payang. Jurnal IPTA pISSN, 5(1), 2017.
Putrawan, I. P., Dewi, L. G. L. K., \& Wijaya, N. M. S., : Karakteristik Motivasi Dan Persepsi Wisatawan Mancanegara Terhadap Jasa Pelayanan Shuttle Bus Di Daerah Ubud, Giayar. Jurnal IPTA.

Supriyati, N. Metode Penelitian Gabungan (Mixed Methods).

Yoeti, O. A. (1996). Pengantar ilmu kepariwisataan. Bandung: Pradya Paramita.

Rai Utama, I. G. B. \& Eka Mahadewi, N. M., 2012. Metodologi Penelitian Pariwisata dan Perhotelan. Yogyakarta: Penerbit Andi.

Sugiyono, 2014. Metode Penelitian Kuantitatif Kualitatif dan $R \& D$. Bandung: Alfabeta.

Suwena, I. K. \& Widyatmaja, I. G. N., 2017. Pengetahuan Dasar Ilmu Pariwisata. Denpasar: Pustaka Larasan.

Ni Made, R. (2019). Pengetahuan Pariwisata Bali. 